\title{
Pegylated Paclitaxel
}

National Cancer Institute

\section{Source}

National Cancer Institute. Pegylated Paclitaxel. NCI Thesaurus. Code C63476.

A formulation of polyethylene glycol (PEG) conjug ated paclitaxel, a compound extracted from the Pacific yew tree Taxus brevifolia, with antineoplastic activity. Paclitaxel binds to and stabilizes tubulin molecules, thereby interfering with the dynamics of microtubule assembly/disassembly and resulting in the inhibition of cell division. This agent also induces apoptosis by binding to and blocking the function of the apoptosis inhibitor protein B-cell Leukemia 2 (Bcl-2). Compared to paclitaxel alone, pegylated paclitaxel has an enhanced water solubility leading to an increase in bioavailability, and decreases its toxicity profile. Therefore, the pegylated formulation potentially supports delivery of higher doses of paclitaxel to the specific site. 